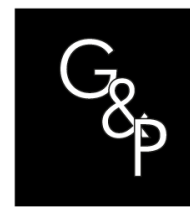

\title{
The different characteristics of real options in contracts of wind power in Brazil
}

\author{
As diferentes características de opções reais em contratos de energia \\ eólica no Brasil \\ Vanderson Aparecido Delapedra-Silva ${ }^{1}$ (D) \\ ${ }^{1}$ Universidade de Brasília - UnB, Programa de Pós-graduação em Administração - PPGA, Brasília, DF, Brasil. E-mail: \\ vanderson.economia@gmail.com
}

How to cite: Delapedra-Silva, V. A. (2021). The different characteristics of real options in contracts of wind power in Brazil. Gestão \& Produção, 28(4), e5652. http://doi.org/10.1590/1806-9649-2021v28e5652

\begin{abstract}
This paper investigates the existence of uncertainties in different wind power commercialization contracts in Brazil and their correlation with the Real Options associated with unmitigated risks in the Back up Energy and New Energy contracts. From a documentary review of existing contracts from 2009 to 2018, it was found that the Real Options on New Energy contracts are more susceptible to market uncertainties related to energy price in the short-term market. The Real Options associated with risks not mitigated in Back up Energy contracts are more linked to uncertainties regarding the power generation efficiency and the project plant expansion capacity in order to generate the anticipation of its supply.
\end{abstract}

Keywords: Renewable energy; Real options; Project Finance; Wind power.

Resumo: Este trabalho investiga a existência de incertezas em diferentes contratos de comercialização de Energia Elétrica de fonte eólica no Brasil e sua correlação com as Opções Reais associadas aos riscos não mitigados nos contratos de Energia de Reserva e Energia Nova. A partir de uma análise documental dos contratos existentes no período de 2009 a 2018, foi verificado que as Opções Reais em contratos de Energia Nova estão mais suscetíveis a incertezas de mercado relacionadas ao preço da energia no mercado de curto prazo. Já as Opções Reais associadas aos riscos não mitigados em contratos de Energia de Reserva estão mais vinculadas a incertezas existentes na eficiência da geração de energia e na capacidade de ampliação da planta do projeto a fim de gerar a antecipação de seu fornecimento.

Palavras-chave: Energia renovável; Opções reais; Project Finance; Energia eólica.

\section{Introduction}

Infrastructure investments are directly associated with the increase of the country's Gross Domestic Product, which can generate a return of US\$ 1.59 for every dollar invested in this segment. However, despite the growing demand for investments in this sector, the role of private companies is still modest and incipient around the world (Esty, 2014).

Despite this, the improvement of financing mechanisms has enabled an increase in the participation of private companies in the execution of long-term investments in infrastructure. During the 1990s, the use of Project Finance (PF) as a project financing

Received Sept 2, 2019 - Accepted Dec 17, 2020

Financial support: None.

This is an Open Access article distributed under the terms of the Creative Commons Attribution License, which permits

unrestricted use, distribution, and reproduction in any medium, provided the original work is properly cited. 
instrument contributed to this purpose, growing at a rate of $20 \%$ in the United States (Esty, 2004; Kleimeier \& Versteeg, 2010).

Project Finance financing is based on a specific type of financing for large projects, usually infrastructure, which require long-term capital and are characterized by financing with the project's own cash flow and the creation of a specific company and legally independent, called a Special Purpose Vehicle (SPV), for the exclusive execution of the project (Yescombe, 2002; Gatti et al., 2007; Esty, 2004).

Several measures used to measure project performance, such as cash flow analysis, revenues, growth in market share, among others, point to important signals capable of guiding future managers' decisions regarding these investments (Bernardo \& Chowdhry, 2002; Brealey et al., 2007). Among these alternatives, the Discounted Cash Flow (DCF) analysis presents a perspective of how the project will evolve over time and how its return will be at present value (Graham \& Harvey, 2002; Muñoz-Hernández et al., 2009).

However, in the analysis of the DCF, the assets are assumed to be fixed over time, not allowing the valuation of situations in which there is the possibility for managers to expand the investment, if the project is successful, or to redeem the investment if something goes wrong (Liu \& Ronn, 2020). Considering these fluctuations in the future (environment of uncertainty) and including them as part of the investment cost is a way to improve the mechanisms of a good evaluation by investing or not in a project. This future flexibility can be measured using mechanisms similar to financial options, they are called Real Options.

The contributions of Black \& Scholes (1973) in the effort to price financial options consolidated the basis for the construction of this risk measurement structure in investment projects, paving the way for the incorporation of this option pricing mechanism in the evaluation of real investments under uncertainty. (Brandão \& Dyer, 2005).

The Real Options Term, coined by Myers (1977) to express the options inserted in investment opportunities, such as suspending, postponing or abandoning the investment (Lambrecht, 2017; Collan et al., 2016) is presented as an investor right, but not the obligation, to make a decision about postponing, expanding, contracting or abandoning an investment at a certain cost (strike price) for a certain period of time (option lifetime) (Copeland \& Antikarov, 2001).

Regarding the financing of major infrastructure projects, we highlight the wind power generation sector in Brazil, which has grown exponentially and has become an important alternative source of energy, mainly due to its reduced environmental impact, low-cost production, in addition to the existence of winds at a higher speed during periods of drought in Brazil, enabling the use of wind farms in a complementary way to hydroelectric plants (EPE, 2018; CCEE, 2019a).

In view of this, this work sought to answer the following research question: What real options can be found in wind energy commercialization contracts in Brazil between 2009 and 2018 and how are they categorized? To answer this question, the objective of this paper is to identify and classify the different real options existing in the different types of wind power concession contracts in Brazil. For this, the basis of the 20 existing concession contracts, from 2009 to 2018, was used.

In addition to this introduction, this work is organized in 4 other parts: 1) Theoretical framework, with conceptual elements about Project Finance, FP risks, Real Options, and the application of Real Options in wind power generation contracts; 2) Database, covering the contract investigation structure and its characteristics; 3) discussion and results, containing the result of the survey and the profile of the real options present in the different types of contracts, and finally, 4) Conclusion. 


\section{Project financing}

The financing of projects via Project Finance is based on the results generated by the estimated cash flows of the project itself, containing different levels of risk. The lack of a history of cash flow for this type of investment and the involvement of different actors in the project contribute to increasing the level of uncertainties about this type of financing (Gatti, 2012; Bodmer, 2014).

In addition, it is worth noting that structuring a Project Finance is not a trivial strategy and depends on a tangle of agreements and common interests so that the project in question can be properly analyzed and its risks properly measured.

\subsection{Project finance risks}

The correct measurement of risk is a fundamental element to support investment decisions. In Project Finance, where the contractual nature implies both project risks and credibility and solidity risks for each linked party, the existence of contractual clauses contributes to the mitigation of part of these risks, presenting specific obligations capable of diluting liabilities in around the existing risks (Gatti et al., 2007; Gatti, 2012; Jorion \& Zhang, 2009).

For Nevitt \& Fabozzi (2000) and Gatti (2012), the risks of financing via Project Finance can be divided into three phases, with different characteristics of credit exposure in each of them: i) engineering and construction phase; ii) start-up phase; and iii) operational phase according to the planned specifications.

In the initial phase of the project, where contracts are negotiated, equipment purchased and contracted labor, the risk level of the project increases sharply due to the advance of resources that will be used in the purchase of material, labor and equipment (Nevitt \& Fabozzi, 2000).

In the start-up phase, after the completion of the construction and installation phase, the focus of creditors' concern is based on the effective operation of the plant within the planned cost matrix and with the quantity and price of products within the forecasts. In this case, the risk of this phase is concentrated in the discovery of a project's forecast error when some of these planned premises do not materialize.

Generally, the analysis of credit risk by financial institutions starts from the assumption of analyzes carried out in conventional companies. As the profile of project companies is highly leveraged, the incorporation of the present value of future cash flows (EBITDA) becomes a fundamental element for this business characteristic, as it will demonstrate the source of loan repayments (Connor et al., 2019; Esty, 2004

In the post-completion phase of the works, the careful analysis of data on competition, market, supplier relations, as well as on the sources of raw materials are critical points of a risk analysis for this type of companies.

Gatti (2012) points out that risks based on macroeconomic variables (inflation, exchange rate and interest rate), as well as their consequences, are examples of threats common to both phases of the project. In addition to these, environmental, legal and regulatory risks, as well as political risks, can also be present throughout the project's life cycle.

To mitigate these risks, three basic strategies can be adopted: i) maintain the risk, adopting mitigation measures internal to the SPE; ii) transferring the risk to a counterparty, structuring contracts with clear rights and obligations, capable of assigning responsible persons pertinent to each type of risk; and iii) transferring the risk to a specialized professional agent (insurance company) (Gatti, 2012). 
Considering the complexity of each project, one must also consider the particularity of each type of risk. In this sense, each project must be evaluated separately. Despite this, the analysis of possible mechanisms around each risk can contribute to an overview of its use and effectiveness.

\section{Real option analysis}

In the traditional analysis of investments based on discounted cash flow, future decisions on projects are considered fixed, not allowing managers to expand or rethink investments beyond the initial project estimate. In applying the Real Options method, the value of a company depends not only on the Net Present Value of its assets, but also on the value of future growth options embedded in its valuation (Madlener et al., 2019).

According to Gazheli \& van den Bergh (2018) investments must have three important characteristics: i) They are irreversible (total or partial); ii) There is uncertainty associated with future rewards; and iii) The timing of the investment is variable and may be postponed.

In this sense, studies on Real Options sought to represent the options embedded in the investment opportunities present in the projects, such as suspending, postponing or abandoning the investment, for example (Lambrecht, 2017). The Real Option is, above all, a tool focused on finding solutions to measure the uncertainties found in the project, contributing to the identification of present and future investment opportunities (Zhang et al., 2016; Fan et al., 2020).

The Real Options Term was coined by Myers (1977) to express the options inserted in investment opportunities, such as suspending, postponing or abandoning investment or expansion (Lambrecht, 2017). However, it was the contributions of Black \& Scholes (1973) in the effort to price financial options that provided a basis for the assimilation of concepts to investment projects, opening space for the incorporation of pricing mechanisms for options for evaluating real investments under uncertainty. (Brandão \& Dyer, 2005).

Hardly, infrastructure projects that compete for concessions through auctions make it possible to delay investment in obtaining more information about its viability, reducing its uncertainty. For this reason, this device can be seen as a purchase option, where the company has the opportunity, but not the obligation, to invest, or to give up the investment, according to its choice (Fernandes et al., 2011).

Compared to the possession of a financial option, the possession of a real option gives the right, but not the obligation, for the company to purchase an asset at some future time of its choice, the option presents itself as an opportunity cost to be included as part of the investment cost. The investor exercises the option when deciding to make the investment (Copeland \& Antikarov, 2001).

Several types of real options are presented by Trigeorgis (1999). However, the most common options are highlighted by the author as being: 1) Postponement option; 2) Option of time for construction; 3) Option to change the operational scale; 4) Abandonment option; 5) switch option; and 6) expansion option (Kozlova, 2017).

The postponement options give holders the option to postpone the investment, considering the opportunity to wait for clearer information about the risks of the decision to invest. Thus, the company can explore or postpone the exploration of a particular ore, betting that the resource price will rise and justify a larger investment for its extraction (Trigeorgis, 2007). The options of time for construction are found in situations where the company slices the costs of the project in several stages, creating the option of abandoning the project in the middle of the way if any relevantly unfavorable information appears (Trigeorgis, 2007; Copeland \& Antikarov, 2001). 
The options for changing the operational scale enable the decision to expand, contract, disconnect or restart an investment. This category of option gives flexibility, enabling the option holder to make the most efficient use of resources, either by accelerating production in times of market expansion, or by reducing production when the market is in an unfavorable situation (Trigeorgis, 1999).

The abandonment options occur when the conjuncture becomes totally unfavorable to the continuity of the investment. In this case, the resale of equipment, in addition to other remaining assets, becomes crucial so that the investment is not lost in its entirety. The abandonment option is classified as an American "PUT" option, with the recovery value given by the amount redeemed from the investment (Trigeorgis, 1999; Copeland \& Antikarov, 2001; Myers \& Majd, 2001).

Switch options allow the policyholder the flexibility to decide whether to switch between two operating models in a project. For example, thermoelectric turbines can be turned on when the price of electricity rises or turned off when the price falls (Copeland \& Antikarov, 2001).

Finally, the expansion options allow the borrower to expand the investment in order to better take advantage of future investment opportunities. According to Pindyck (1986), the value of a company's expansion options (growth potential) can represent more than half of its market value.

The use of Real Options has expanded as a methodology for valuing different renewable energy projects, mainly since they have different uncertainties due to different market associations or resource conditions. Several studies have addressed these issues in different parts of the world, such as Brazil (Dranka et al., 2020), PORTUGAL (Santos et al., 2014), USA (Maeda \& Watts, 2019), China (Li et al., 2018), Egypt (Hatata, El-Saadawi \& Saad, 2019), among many others.

The real options projects applied to the valuation of projects based on renewable energy also use the Monte Carlo Simulation method as a support methodology, which allows the analysis of a probability of events to occur, considering some sources of uncertainty. In this sense, some studies address uncertainties related to wind variability (Onar \& Kilavuz, 2015), while others analyze uncertainties related to energy prices (Balibrea-Iniesta et al., 2015), investment costs (Zhang et al., 2016) or market regulation (Eissa \& Tian, 2017; Eryilmaz \& Homans, 2016).

The main function of using the Monte Carlo Simulation method is to make uncertainties more widespread in a probability rule in order to contribute so that decision making has probabilistic parameters of success. Fleten et al. (2016), for example, examined the investor's behavior in hydroelectric projects in Norway, for this, they used as reference, the Net Present Value to assess the viability of investments. In view of the uncertainty inserted in electricity prices in their study, the authors applied the Monte Carlo Simulation method to assess the expected value of a real option in the project. Aquila et al. (2020) studied the feasibility of investments in wind energy in Brazil using the Monte Carlo Simulation method to complement the deterministic analysis of the results. Carvalho et al. (2020) also used the Net Present Value for a deterministic evaluation and combined the use of Monte Carlo simulation for a stochastic evaluation of the results that analyzed the risk associated with the anticipation or delay of the completion of wind and photovoltaic projects in Brazil.

Recently, the uncertainties related to energy prices in works that use Real Options have been accompanied by the discussion about the best stochastic process to be used to estimate a Monte Carlo simulation that is feasible and congruent with the analyzed data series. In this sense, many works adopt the Brownian Geometric Movement (BGM) as a standard, initially assumed as a stochastic process of the evolution of the stock market by Black \& Scholes (1973). Even today, BGM is used as a reference in works using Real Options both for the simulation of values related to the value of renewable energy projects (Liu \& Ronn, 2020) and to the prices of electric energy (Locatelli et al., 2020; Kitzing et al., 2017). 
Despite Aquila et al. (2020) and De Oliveira et al. (2019) defend the use of the stochastic process called Mean Reversion, considering price jumps throughout the process instead of the Brownian Geometric Movement. Penizzotto et al. (2019) highlight that the uncertainties in the future dynamics of electricity tariffs and investment costs can be adequately described by a mixed stochastic process, which combines geometric Brownian motion with jumps following a Poisson distribution. Boomsma et al. (2012) in addition to Ritzenhofen \& Spinler (2016) found that the Brownian Geometric Movement does not bring significant losses as the simulations consider long-term periods, over 20 years.

\subsection{Real options in wind power}

The high costs of investment in renewable energy sources, added to the undervaluation of its benefits in relation to conventional energy sources, in addition to the increase in the uncertainties generated by the competitiveness resulting from the deregulation of the sector, have made the conventional techniques of project evaluation become insufficient to measure these uncertainty factors (Fernandes et al., 2011).

In this sense, when talking about wind energy, in addition to the intrinsic uncertainties present in the variation of winds (Martinez-Cesena \& Mutale, 2011), some works relate the uncertainties of these contracts to variations in product prices (Reuter et al., 2012) the costs of energy production (Wesseh \& Lin, 2016; Cheng et al., 2010) and the cash flow generated by the project (Méndez et al., 2009).

Kozlova (2017) points out that $40 \%$ of the studies related to real options applied to wind power generation are concentrated in a single source of uncertainty in their evaluation model, with the price of electricity as the main one.

Venetsanos et al. (2002) used the methodology of partial differential equations to evaluate the present value of renewable energy projects. For this, they considered the uncertainties and attributes directly related, inherent to the generation of energy. Then the authors identify the real options incorporated in the wind energy project and perform the valuation of the project based on the theory of real options, using the Black-Scholes model. Finally, the authors conclude that the project's Net Present Value (NPV) was positive when considering the influence of real options. However, the NPV did not achieve a positive result when the valuation was made using the traditional model.

Yu et al. (2006) also used numerical techniques and differential equations to assess the impact of physical and market uncertainties associated with wind generation assets in the Spanish electricity market. Using a time series model, the forecast of electricity prices in that country is simulated assuming the Brownian Geometric Movement. The real options used by Yu et al. (2006) are of the type of composite options, which assess the flexibilities associated with exchange rates.

Muñoz et al. (2009) used a stochastic model to analyze the parameters that affect the NPV of wind energy investment projects. For this, they compared traditional techniques for analyzing the feasibility of these projects with the evaluation methods with real options. The real option explored by the authors is to postpone, seeking to calculate the premium that a company must pay for the option to postpone its investment.

Barroso \& Iniesta (2014) also used real options to analyze a proposed investment in wind power generation in the German market. In this sense, the authors modeled the primary uncertainties that affect the project and incorporated the uncertainties arising from government incentives.

Gazheli \& van den Bergh (2018) explored real options to investigate three cases with investment possibilities between wind and photovoltaic energy and concluded that the 
uncertainties regarding future prices and energy costs induce an investment decision in just one type of energy source, mainly due to the initial costs and the learning rates of each technology. Zhang et al. (2016) used the concept of Real Options to assess uncertainties related to the price of $\mathrm{CO} 2$, the cost of non-renewable energy, the market price of electricity and the cost of investment.

Wesseh \& Lin (2016) also used the Real Options theory to assess wind energy projects in China. The authors considered the variation in non-renewable energy costs as the main factor of uncertainty. The authors highlighted the need to consider the incentive tariffs provided by the Chinese government for the sector, as well as the costs related to $\mathrm{CO} 2$ emissions as intrinsic costs of the projects. Thus, the authors concluded that the Real Options could be used to guide policies for the calibration of subsidy rates.

The timing of the investment is also analyzed using real options by Fleten \& Maribu (2004), for this, the author analyzes the volatility of electricity prices to identify the best time to start the investment. The author also explores the break-even price of the project's $\mathrm{NPV}$, based on the influence of uncertainty in the price of electricity.

In Brazil, Aquila et al. (2020) used the real options method to investigate the feasibility of a wind energy project with the option of abandoning it over the life cycle of the project. The authors analyze the aspect of the uncertainties inserted in the revenues from sales of electricity in the spot market. Pelajo et al. (2019) also used the Real Options method to evaluate wind farms in Brazil, however, the authors analyzed the real options for postponing the maintenance process of the plant's generators so that the period spent in this process has the best efficiency possible.

Zhang et al. (2020), in turn, used real options to identify prices that would bring a balance point for wind energy enterprises in China, considering the scenario where the government plans to reduce or extinguish subsidies and where the authors defend the gradual reduction of subsidies in large part of the country. Considering regulatory changes, Madlener et al. (2019) used Real Options to investigate the expansion of capacity and the technological development of wind power generators in German plants considering the impacts that these regulatory changes have on the profitability of these wind farms.

Finally, most studies on the theory of real options applied to wind energy projects model uncertainties related to the variation of wind and electricity prices, resulting in uncertainties related to the cost of production and the cash flow generated by the projects. In turn, cash flow volatility can be used as an input for calculating real options. Among the most widespread methods, the binomial tree method proposed by Cox et al. (1979) used the calculation of the project's volatility to subsequently calculate the nodes for each period of the decision tree. With the nodes mapped, it is possible to calculate the differences in the values of the projects without flexibility in each scenario and the respective value of each real option embedded in each moment.

Finally, Liu And Ronn (2020) used the binomial tree method to identify real options in renewable energy projects in China in order to assess the appropriate subsidy for exercising the real option of the projects analyzed by investors.

\section{Commercialization of wind energy in Brazil}

The main source of electricity in Brazil is large-scale hydraulics, which is complemented by thermal plants, especially in times of low hydro generation. However, Brazil has enormous energy potential arising from renewable sources to be explored, demanding constant regulatory and technological innovations in the sector (CCEE, 2019a).

Despite representing $8.7 \%$ of the total energy generated in Brazil, the country has great potential for generating energy from wind sources, mainly due to the presence of 
winds that exceed twice the world average, with a volatility of only $5 \%$, giving greater predictability to the volume produced by its plants (CCEE, 2019b).

Brazil's dependence on energy generated by large hydroelectric plants makes it hostage to reservoirs capable of generating driving force for these turbines. In times of drought, Brazil is more exposed to this hydrological risk and uses a thermal energy generation system with more expensive generation costs. This lack of capacity to generate electricity from hydraulic sources, combined with the increase in energy demand and the entry of new projects in the system are factors used for the periodic calculation of energy generation considered optimal to meet the demand for electricity safely Throughout the national territory.

With the inputs of this calculation, it is possible to estimate the Marginal Operating Cost (CMO, in the Portuguese acronym) for each load level and for each submarket existing in the national electricity system. The $\mathrm{CMO}$, in turn, is the main reference for calculating the Difference Settlement Price (PLD, also in the Portuguese acronym) that will be used to sell energy in the so-called Short-Term Market (CCEE, 2019c).

The Short-Term Market is the environment where there is a settlement of energy differences between generators and consumers. In this way, when the plants are not able to generate the amount of energy that they have offered in the auctions they participated in, they are subject to buying energy in this market as a way to meet their supply requirement and the price exercised in that market is precisely the Price of Settlement of Differences (PLD).

This drought risk, or hydrological risk, also directly impacts the price of energy to final consumers. In this sense, the use of wind energy in Brazil has the potential to supply this demand and mitigate this risk, since it has lower production costs and the possibility of using the incidence of more favorable winds in times of drought (EPE, 2018).

Currently, two environments regulate commercial energy relations in Brazil: the Regulated Contracting Environment ( $A C R$ ) and the Free Contracting Environment ( $A C L)$. In the first, the purchase and sale of energy is formalized by contracts between the generating agents and distributors through auctions for the purchase and sale of energy, while in the free environment, agents are free to negotiate and establish contracts that formalize the purchase volumes. and sale of energy, as well as their respective prices.

In the Regulated Contracting Environment, auctions for the purchase and sale of electricity were characterized by two different types of modalities until the first half of 2018: "by Quantity", where the risks for the generation of the amount of contracted energy are assumed by the generators; and "by Availability", where the distributors assumed any risks of power generation due to uncontrolled factors (CCEE, 2019a).

In addition to these environments, the wind energy market in Brazil also has three main types of contracts: Back up Energy Contracts; New Energy Contracts; and Alternative Energy Contracts.

The price of energy in the ACR is determined by auctions, while the price of energy traded in the ACL is determined freely by the agents, in bilateral contracts.

\subsection{Backup Energy Contracts (CER)}

The contracting of Back up Energy was regulated by Decree $n^{\circ}$ 6,353 (Brasil, 2008), and its inductor was the guarantee of the continuity and sufficiency of the supply of electric energy in Brazil in periods of scarcity and imbalance in the supply.

According to the Decree, Backup Energy is regarded as that which seeks to increase the security of electricity supply to the National Integrated System (SIN), from plants contracted especially for this purpose. 
Backup Energy Contracts (CER) are entered into exclusively through periodic auctions that take place according to the need for additional energy generation to the system and are disclosed in the quantity modality (CCEE, 2019a).

As it has a greater degree of uncertainty than other sources, the calculation of the delivery of the contracted energy to wind farms has some particularities, such as the contract for four years, in addition to the amount delivered annually by the contract.

As a result, the contract has a tolerance range called the Backup Energy Account (CONER) which establishes the amount of $90 \%$ at its lower limit and $130 \%$ at its positive limit of the amount of energy contracted annually.

Therefore, if the annual amount is below $90 \%$ of the annual contracted limit, the reimbursement is calculated, if this amount is above the positive limit, the variable surplus revenue is calculated.

Quadrennial, the reimbursement also occurs, in case the balance of the energy bill becomes negative. Otherwise, if there is a positive balance, the plant can transfer the balance to the following four-year period, assign four-year energy to other wind projects in the same auction, or receive variable revenue from the accumulated balance at CONER (CCEE, 2019a).

In the Backup Energy contracts until 2011, the remuneration for power generation in negative quantities within the tolerance range ( $10 \%$ lower than the contracted energy) was linked to the sale price established in the auction. In contracts starting in 2013, this remuneration increased to a reference of 1.06 times that of the sale price.

\subsection{New Energy Contracts (CCEAR)}

The New Energy Auctions are used by the government in order to expand the power generation plants in Brazil. Since 2005, distribution agents, vendors, self-producers and free consumers have assumed the obligation to inform the forecasts of their markets or energy loads for the subsequent five years (DECREE No. 5.163, 2004) (Brasil, 2004).

However, from 2006 onwards, all distribution agents were obliged to submit to the Ministry of Mines and Energy, the declaration of the necessary amounts for contracting energy to be acquired through auctions (DECREE 9.143, 2017) (Brasil, 2017), inducing the government establishes the amount of energy to be contracted through this type of auction.

Except for auctions that would take place after the middle of 2018, which established the "by quantity" modality, all previous contracts of this type of energy were classified in the "by availability" contracts modality, which paid the sellers with a fixed amount for the availability of plants with a certain generation capacity, in addition to a marginal value for each megawatt generated.

As a rule, the remuneration for the generation of Energy in New Energy contracts, unlike what occurs in Backup Energy Contracts, considers two remuneration indices, in addition to the fixed remuneration for the project for contracts prior to 2018 .

One of these indexes is used to remunerate the percentage of the installed power of the generating units committed to the contract and which is not in commercial operation after the dates provided for in the granting act.

The other index refers to the remuneration of the remaining amount that is in operation after these dates. Generally, the remuneration for the delayed installed power has a discount of $15 \%$ in relation to the remuneration for the installed power of the generating units that started commercial operation on the scheduled date.

The main difference between the New Energy contracts in the "by availability" modality of the last contract of this type of energy, in the "by quantity" modality, is due to the way in which the project's sales revenue is described in the contracts. 
Previously, due to the "by availability" modality, the contracts allowed the remuneration of the project weighted by the fixed revenue linked to the generating units committed to the contract and that had not entered into operation until the date foreseen in the granting act, considering the remuneration of part of the energy anticipated by the project.

In the New Energy contract in the "by quantity" modality, the fixed remuneration was extinguished, and the sale price established in the auction started to be used as a reference for the installed power that was up to date with the dates foreseen in the contract. In addition, the discount with negative goodwill started to be applied to the generating units that had not entered into operation after the dates established in the contract.

Finally, Energy from Alternative Sources appears as an alternative to serve the consumer market of distribution concessionaires, making it possible to carry out auctions for the purchase of energy from alternative sources, regardless of the date of grant (DECRETO 6.048, 2007) (Brasil, 2007).

However, the low potential for new auctions to appear means that the risks of these contracts are not relevant for an analysis of future investment opportunities, and it is convenient to compare them to new energy contracts without the specificities of a new grant by the granting authority.

\section{Data base and methodology}

This research is categorized as descriptive and exploratory, with a qualitative approach, and supported by documentary analysis. The object analyzed are all contracts for the sale of electric energy from wind sources in Brazil between the years 2009 to 2018 . In addition, the interpretative nature of the research required a classification of standards found in each contract in order to draw conclusions about changes over the analyzed period could be evidenced.

For the classification of standards and relevant information for each contract, the procedures described in the following research protocol illustrated by Table 1 were adopted.

Table 1. Qualitative Research Protocol.

\begin{tabular}{|c|c|c|c|}
\hline Sequence & Objective & Procedure & Expected Results \\
\hline $1^{\text {st }}$ & $\begin{array}{c}\text { To Build a base of } \\
\text { documents of interest for } \\
\text { research }\end{array}$ & $\begin{array}{c}\text { Selection and obtaining of Contracts for } \\
\text { the Commercialization of Wind Energy in } \\
\text { Brazil }\end{array}$ & $\begin{array}{l}\text { General set of documents } \\
\text { of interest for research }\end{array}$ \\
\hline \multirow{4}{*}{$2^{\text {nd }}$} & \multirow{4}{*}{$\begin{array}{l}\text { To Categorize } \\
\text { documents }\end{array}$} & \multirow{4}{*}{$\begin{array}{c}\text { Identify and separate specific types of } \\
\text { contracts }\end{array}$} & Three sets of contracts: \\
\hline & & & a) New Energy; \\
\hline & & & b) Backup Energy; and \\
\hline & & & c) Alternative Sources \\
\hline $3^{\text {rd }}$ & $\begin{array}{l}\text { To Map Common } \\
\text { clauses in equal groups }\end{array}$ & $\begin{array}{l}\text { Analytical reading of each contract } \\
\text { separately by group in order to select } \\
\text { common clauses }\end{array}$ & $\begin{array}{l}\text { Common clauses within } \\
\text { each set of analyzed } \\
\text { contracts }\end{array}$ \\
\hline $4^{\text {th }}$ & $\begin{array}{l}\text { To Map different clauses } \\
\text { in equal sets }\end{array}$ & $\begin{array}{l}\text { Analytical reading of each contract } \\
\text { separately by group in order to select the } \\
\text { differences between the clauses }\end{array}$ & $\begin{array}{l}\text { Different clauses within } \\
\text { each set of analyzed } \\
\text { contracts }\end{array}$ \\
\hline $5^{\text {th }}$ & $\begin{array}{l}\text { To Map common } \\
\text { clauses in contracts of } \\
\text { different sets }\end{array}$ & $\begin{array}{l}\text { Analytical reading of each contract } \\
\text { separately by clause in order to identify } \\
\text { common contracts in different groups }\end{array}$ & $\begin{array}{l}\text { Common clauses within } \\
\text { different sets of contracts } \\
\text { analyzed }\end{array}$ \\
\hline $6^{\text {th }}$ & $\begin{array}{l}\text { To Map Different } \\
\text { clauses in different sets } \\
\text { of contracts }\end{array}$ & $\begin{array}{l}\text { Analytical reading of each contract } \\
\text { separately by clause in order to identify } \\
\text { differences between groups }\end{array}$ & $\begin{array}{l}\text { Different clauses in } \\
\text { different sets of contracts } \\
\text { analyzed }\end{array}$ \\
\hline $7^{\text {th }}$ & $\begin{array}{l}\text { To Track differences } \\
\text { across contract timelines }\end{array}$ & $\begin{array}{l}\text { To Create a timeline containing important } \\
\text { differences in clauses and the group of } \\
\text { ownership responsible for the differences }\end{array}$ & $\begin{array}{l}\text { Clause detail map } \\
\text { considering different } \\
\text { groups of contracts over } \\
\text { the period of interest }\end{array}$ \\
\hline
\end{tabular}


We analyzed twenty wind energy commercialization contracts in Brazil, from 2009 to 2018. Of the total of 20 auctions held, 17 had lots composed of different energy generating sources, while three auctions took place exclusively with lots originating from wind source. Table 2 illustrates the number of contracts containing exclusive lots of wind energy.

Table 2. Quantity of Wind Energy Contracts.

\begin{tabular}{ccc}
\hline Modality & Contracts & Exclusive contracts \\
\hline Backup Energy & 6 & 2 \\
\hline Alternative sources & 2 & 0 \\
\hline New Energy & 12 & 1 \\
\hline Total & 20 & 3 \\
\hline
\end{tabular}

The market governed by the Regulated Environment negotiates energy via contracts for the sale of energy from the regulated environment (CCEAR), which can be of the "by Quantity" type, where those who sell commit to delivering a quantity of megawatts / hour, or "by availability", where the risk of hypoventilation and commitment to reducing the amount of energy generated is assumed by the buyer.

In the case of auctions of the Backup Energy type, the contracts are made up of the "by quantity" modality, although the auctions of New Energy contracts, until 2018, were characterized as "by Availability".

It is worth mentioning that the only New Energy contract signed in the "by quantity" modality was the contract of the auction $03 / 2018$, the last auction held to generate energy from this source.

The methodology of this paper is based on a document analysis, with a qualitative approach, as it seeks to identify elements inserted in the context of each contract analyzed, in addition to analyzing all documents in the light of the historical evolution of the energy commercialization process in the regulated market.

Figure 1 seeks to illustrate the methodological procedure used in the research:

\begin{tabular}{|c|c|}
\hline $\begin{array}{c}\text { Step } 1 \\
\text { Identification and reading }\end{array}$ & $\begin{array}{l}\text { Procedure for identifying the documents to } \\
\text { be analyzed, their period and consequent } \\
\text { reading. }\end{array}$ \\
\hline $\begin{array}{c}\text { Step } 2 \\
\text { Risk Selection }\end{array}$ & $\begin{array}{l}\text { Mapping of existing risks in the contracts } \\
\text { read, selecting highlights. }\end{array}$ \\
\hline $\begin{array}{c}\text { Step } 3 \\
\text { Risk Grouping }\end{array}$ & $\begin{array}{l}\text { Identification of common risks between the } \\
\text { contracts analyzed. }\end{array}$ \\
\hline $\begin{array}{c}\text { Step } 4 \\
\text { Mitigators }\end{array}$ & $\begin{array}{l}\text { Identification of mitigators for the mapped } \\
\text { risks. }\end{array}$ \\
\hline $\begin{array}{l}\text { Step } 5 \\
\text { Real Options Identification }\end{array}$ & $\begin{array}{l}\text { Relationship between unmitigated risks and } \\
\text { their role as real investment options. }\end{array}$ \\
\hline
\end{tabular}

Figure 1. Research methodological procedures. 
Initially, all documents object of this paper were read, namely, the Backup Energy contracts (CER) and the New Energy contracts (CCEAR). Next, highlights were selected related to possible risks inserted in the context of the documents. In a third moment, a grouping of possible common risks between the contracts and the main differences between them was carried out, allowing both a general analysis of its historical evolution and an individual analysis of each contract. Then, the existing mitigations for each identified risk were identified. Finally, the risks with insufficient mitigators for each contract were highlighted, making it possible to establish a relationship between the risks of the contracts and the existence of real options inserted in these investments.

\section{Results and discussion}

The analysis of the contracts (object of this study) allowed the identification of the idiosyncrasies of each type of contract, in addition to raising several focuses of risk related to the most diverse uncertainties of each clause.

As already mentioned, Kozlova (2017) points out that $40 \%$ of the studies related to the real options applied to the generation of wind energy are concentrated in a single source of uncertainty, especially the price of energy. However, other uncertainties can be considered. However, uncertainties related to investments, the amount of energy produced, as well as the consumer price index can also contribute to the expansion of the range of uncertainties in these types of contracts (Barroso \& Iniesta, 2014).

Many risks analyzed in investment projects are not related to uncertainties that allow for future managerial flexibility, or they have mitigators within the contract or related to some rule. This work makes a broader analysis of risks in wind energy contracts in Brazil. From a documentary analysis, it was possible to identify details related to possible uncertainties inserted both in the Backup Energy contracts and in the New Energy contracts between the period covered in the study.

The most common risks identified in the contracts are related to market and operational uncertainties, both in the Backup Energy contracts and in the New Energy contracts. The risks related to Alternative Energy contracts were very similar to the New Energy contracts.

Uncertainties regarding the market price of energy in the free environment directly impact the decision of the ventures regarding the availability of energy for the regulated market. In addition, operational uncertainties related to anticipation and excess energy generation are risks that impact the turnover of projects based on the prices defined in the auctions.

The financial risks of the contracts are related to the variation in inflation, in addition, all contracts warn of the existing risks of delay in the works and in the supply of energy (completion).

Finally, the legal risks are related to the possibility of bankruptcy of the projects and to the charges, tariffs and taxes existing in the power transmission and generation system.

Table 3 compiles the number of risks found per contract in the period of interest for the study.

Table 3. Risks in Wind Energy Contracts.

\begin{tabular}{cccccccc}
\hline Year & Type of Contract & $\mathbf{C}$ & $\mathbf{F}$ & $\mathbf{L}$ & $\mathbf{M}$ & $\mathbf{O}$ & Total \\
\hline 2009 & LER & 1 & 1 & 2 & 2 & 5 & 11 \\
\hline 2010 & FA & 1 & 1 & 2 & 2 & 2 & 8 \\
\hline 2010 & LER & 1 & 1 & 2 & 3 & 5 & 12 \\
\hline 2011 & A-3 & 1 & 1 & 2 & 3 & 1 & 8 \\
\hline 2011 & A-5 & 1 & 1 & 2 & 3 & 5 \\
\hline 2011 & LER & 1 & 1 & 2 & 3 & 1 & 12 \\
\hline 2012 & A-5 & 1 & 1 & 2 & 3 & 1 & 8 \\
\hline 2013 & A-3 & 1 & 1 & 2 & 3 & 1 \\
\hline
\end{tabular}


Table 3. Continued...

\begin{tabular}{|c|c|c|c|c|c|c|c|}
\hline Year & Type of Contract & C & $\mathbf{F}$ & $\mathbf{L}$ & $\mathbf{M}$ & 0 & Total \\
\hline 2013 & A-5 & 1 & 1 & 2 & 3 & 1 & 8 \\
\hline 2013 & LER & 1 & 1 & 1 & 3 & 5 & 11 \\
\hline 2014 & A-3 & 1 & 1 & 2 & 3 & 1 & 8 \\
\hline 2014 & A-5 & 1 & 1 & 2 & 3 & 1 & 8 \\
\hline 2014 & LER & 1 & 1 & 1 & 3 & 5 & 11 \\
\hline 2015 & A-3 & 1 & 1 & 2 & 3 & 1 & 8 \\
\hline 2015 & $\mathrm{FA}$ & 1 & 1 & 2 & 2 & 2 & 8 \\
\hline 2015 & LER & 1 & 1 & 1 & 3 & 5 & 11 \\
\hline 2017 & $A-4$ & 1 & 1 & 2 & 3 & 1 & 8 \\
\hline 2017 & $A-6$ & 1 & 1 & 2 & 3 & 1 & 8 \\
\hline 2018 & $A-4$ & 1 & 1 & 2 & 3 & 1 & 8 \\
\hline 2018 & $A-6$ & 1 & 1 & 2 & 3 & 1 & 8 \\
\hline Total & & 20 & 20 & 37 & 57 & 46 & 180 \\
\hline Average & & 1 & 1 & 1,85 & 2,85 & 2,3 & 9 \\
\hline
\end{tabular}

$\mathrm{C}=$ Completion; $\mathrm{F}=$ Financial; $\mathrm{L}=$ Legal; $\mathrm{M}=$ Market; $\mathrm{O}=$ Operational.

\subsection{Risks in backup energy contracts}

The risks of the Backup Energy contracts are mainly related to the operational efficiency of the plants. The fact that there is no margin for the negotiation of excess energy with other agents of the free environment contributes to the plant's remuneration being linked to its operational efficiency, being refunded when it produces a quantity that exceeds the contracted energy, and when it produces quantities below contracted energy.

Table 4 illustrates the different types of risks found in Backup energy contracts, showing the type of risk and its details.

Table 4. Types of Risks in Backup Energy contracts.

\begin{tabular}{l}
\hline Types of Risks \\
\hline Completion \\
\hline Delay in plant start-up \\
\hline Financial \\
\hline Inflation \\
\hline Legal \\
\hline Transmission system tariff and tax charges \\
\hline Bankruptcy \\
\hline Market \\
\hline Use of not new generators or with previous use \\
\hline Wind turbines unavailable at a higher level than the benchmark performance indexes \\
\hline Use of generators with rated power below 1,500 kW \\
\hline Operational \\
\hline Destination of surplus energy generated - Transfer, Settlement or Assignment \\
\hline Annual generation below 90\% of the contracted energy (6\% higher reimbursement from 2013) \\
\hline Anticipation of energy supply based on variable revenue \\
\hline Surplus energy production above the tolerance range \\
\hline Surplus energy production within the tolerance range \\
\hline Destino do excedente de energia gerado - Repasse, Liquidação ou Cessão \\
\hline
\end{tabular}

\subsubsection{Completion risks}

In all Backup Energy contracts, completion risks are identified both in clauses that warn about the financial risks associated with the difference between generated energy and 
contracted energy, arising from the delay in the plant's start-up date, and in a clause that includes penalty of termination of the contract if there is a delay in starting the plant's commercial operation after a certain period.

Backup Energy contracts have mitigators for this type of risk, such as the requirement for a physical schedule of the works in the notices, a device for reconciling the quantity contracted in the first contracts. Accordingly, the completion risk itself is reflected in the operational risk of not generating energy as provided for in the contract.

\subsubsection{Financial risks}

The only relevant financial risk identified in the Backup Energy contracts is related to the variation in the sale price used as a reference for the project's remuneration. In this case, the mitigator for this type of risk is presented by clauses for the annual adjustment of this indicator.

\subsubsection{Legal risks}

The legal risks of Backup Energy contracts are related to charges, tariffs and taxes that may impact the plants. For this type of risk, the mitigators present in the contracts determine that the plants are not responsible for this type of expense that may appear after the contract is signed.

In addition, the bankruptcy of the plants is also treated in the contracts as a determining factor for their termination. In this case, this type of risk was understood to be mitigated from the moment the generating units receive technical qualification before participating in the service concession.

\subsubsection{Market risks}

The lack of wind turbines on the market cannot be a factor in the termination of the contract when the equipment is not available for sale. Therefore, this type of risk does not entail the existence of a real option for the analyzed Backup Energy contracts.

\subsubsection{Operational risks}

In the Backup Energy Contracts analyzed, one of the factors of poor performance of the project plant concerns the occurrence of winds at a lower intensity than planned, implying a risk of low energy production and, consequently, failure to reach the goal established in the signing of the contract. contract.

In the first Backup Energy contracts, this risk was mitigated by contractual reconciliation clauses, which made it possible to adjust the amount of energy generated from an average of previous four-year periods. The loss of this device gave rise to a greater operational risk of variation in power generation for generating projects.

In addition, the remuneration for the difference (positive or negative) between energy generated and energy contracted for this type of contracts has changed over the years, and as of 2013 , the reimbursement for energy generated below the tolerance range was $6 \%$ more expensive as of 2013.

Another positive aspect of the Backup Energy Contracts is the existence of advance revenue remuneration for the plant that decides to advance the energy supply (option to change the operational scale), considering the date stipulated in the contract for the start 
of operations. This term was established at three years for all contracts, except the last one, in 2015, which stipulated the term for starting operations at two years.

This prerogative presents itself as an opportunity for companies competing in the Backup Energy auctions, since they allow them to decide whether to anticipate, or not, the conclusion and start of operation of the plant. It is worth noting that the variable revenue received by the plant for surplus energy within the delivery period is $30 \%$ less than the variable revenue obtained from the anticipated energy.

On the other hand, the amount of reimbursement due by the plant in cases where the accumulated balance annually exceeds the minimum limit of the tolerance range will have a cost of $15 \%$ higher than the variable revenue obtained for amounts of anticipated energy, whose reference value is given by the sale price established in the auction.

Another positive aspect of Backup Energy contracts is the possibility for the seller to decide, every four months, between: 1) Transfer the amount of energy to the following quarter, when there is energy credit; 2) assign the amount, or part of it, to another seller at the same auction; and 3) settle the receipt of excess energy (Switch option).

This type of future managerial flexibility at the beginning of the project leads to the existence of a specific type of option, giving the manager the opportunity to optimize his decision regarding surplus energy in order to improve the plant's revenue. For this type of uncertainty, the real option of Switch was the one that best expressed this characteristic.

\subsubsection{Real options in backup energy contracts}

In view of all possible uncertainties in the Backup Energy contracts, the most evident are related to the variability in the occurrence of winds, which will directly impact the supply of energy. In this case, the occurrence of lower-than-expected winds can influence the decision to abandon the project in different parts of the project (Time for construction).

In addition, the existence of uncertainties related to the future excess amount of energy also influences the future remuneration of the seller, changing the net present value of the project.

The opportunity generated by the remuneration of the anticipated energy is also a factor that can impact the net present value of the project, since depending on the auction's winning sale price, anticipating the energy supply can be a positive alternative for the seller. The option to change the operational scale is associated with this type of uncertainty.

Finally, the decision between transferring, assigning, or liquidating the surplus amount of energy is also linked to uncertainty regarding the sale price associated with the winning bid submitted by the seller at the auction, depending on the winning price, different strategies can support the seller's decision as to the destination of the surplus amount of energy generated. The Exchange option is associated with this type of uncertainty.

Therefore, the real options most congruent with this contract structure would be the options of 1) Time for construction; 2) Changing of the Operational Scale; and 3) Switch Options.

The other risks found in the Backup Energy contracts do not give rise to the possibility of managerial flexibility capable of increasing the project's profitability or minimizing losses. Table 5 shows the real options found in the Backup energy contracts based on the unmitigated uncertainties in these contracts.

Table 5. Real Options in Backup Energy Contracts.

\begin{tabular}{cccc}
\hline Type of Contract & Type of Risk & Uncertainty & Real Options \\
\hline Backup Energy & Operational & Amount of Energy Generated & Time for Construction \\
\hline Backup Energy & Operational & Amount of Energy Generated Changing of the Operational Scale. \\
\hline Backup Energy & Market & Energy Assignment & Switch Options. \\
\hline
\end{tabular}




\subsection{Risks in New Energy contracts}

The relevant risks identified in New Energy contracts are mainly based on risks related to the supply of energy and the future opportunity to supply energy to the free environment. Unlike the Backup Energy contracts, the New Energy contracts were remunerated by a fixed revenue established at auction and their quantity was marked by a percentage of the energy produced by the plant.

As of the auction contract $03 / 2018$, the New Energy contract, which changed to the "by quantity" modality, started to remunerate the contracted energy from the sale price established in the auction, allowing the enterprise to decide on the amount to be allocated in the bid that best suits your interests (considering the minimum of $30 \%$ of the energy produced).

Another factor that differentiated the last contract in this modality is the loss of the $90 \%$ tolerance range of the contracted energy in order to be reimbursed by the seller, leaving him exposed to the short-term market when there is a reduction in the quantity established in the auction.

Table 6 illustrates the different types of risks found in new energy contracts, showing the type of risk and its details.

Table 6. Types of Risks in New Energy Contracts.

\begin{tabular}{l}
\hline \multicolumn{1}{c}{ Types of Risks } \\
\hline Completion \\
\hline Delay in plant start-up \\
\hline Financeiro \\
\hline Inflation \\
\hline Legal \\
\hline Transmission system tariff and tax charges \\
\hline Bankruptcy \\
\hline Market \\
\hline The use of generators not new and with previous use \\
\hline Wind turbines unavailable at a higher level than the benchmark performance indexes. \\
\hline Use of generators with rated power below 1,500 kW \\
\hline Auction Sale Price lower than the Free Market Price \\
\hline Fixed revenue lower than the Free Market Price ("by availability") \\
\hline Operational \\
\hline Annual generation below $90 \%$ of the contracted energy \\
\hline
\end{tabular}

Completion, financial and legal risks do not vary in relation to what has already been highlighted in the Backup Energy contracts. All the New Energy contracts have the same mitigators as the Backup Energy contracts.

\subsubsection{Market risks}

Regarding to the market risks existing in New Energy contracts, it is worth mentioning that in this type of contract, the seller has the alternative of, from the date of the plant's commercial operation, selling with any agent of the free environment, in the market shortterm, or if applicable, in auctions for the purchase of Energy, the portion of physical guarantee not committed to the sale contracts entered into in the regulated environment. 
This possibility influences the decision to be taken by the enterprise at the time of bidding at the auction. Because, if the price of energy in the free environment is being negotiated at a price higher than the market price in the regulated environment, the amount reserved to be sold in the free environment can generate higher revenue for the enterprise.

\subsubsection{Operational risks}

In the New Energy contracts prior to the last auction (auction 3/2018), the specific subclauses of the clause referring to the obligation of energy delivery by the seller regulated the amount of energy to be supplied in different periods of the project.

In this sense, if the first generating unit of the plant did not start operating, the amount of energy committed to be delivered by the seller would be the amount of energy contracted. In contrast, after the plant's last generating unit went into operation, this amount would be given by the total energy produced, weighted by the percentage of the physical guarantee.

While this characteristic also gave the seller flexibility to negotiate the surplus energy with other agents, it also linked a percentage of energy (mandatory physical guarantee) to the total energy produced by the plant.

As the auction contract $03 / 2018$ started to be governed by the "by quantity" modality, its uncertainty as to future revenue increased, since "New quantity" contracts of New Energy remunerate the energy in a variable way, by the amount of energy contracted.

Another important factor regarding future uncertainties concerns the amount of energy traded in the ACR by the project and its offer at the auction. In this regard, the Energia Nova notices until the year 2017 indicated a minimum amount of $70 \%$ of the physical guarantee at the plant. As of the 2017 notices, however, this minimum amount was changed by ANEEL's decision to $30 \%$ of the energy enabled in the project. There is no clear notification in the public notice to justify this change by ANEEL, but it is possible to verify that the focus of analysis of the wind energy generating projects started to focus on the generation of the projects instead of their carrying capacity.

This possibility of a minimum energy limit to be negotiated in the ACR is a factor of uncertainties for the project since the existing trade-off between the amount of energy negotiated in the ACR and the ACL may occur due to the future price variation in these two environments (Exchange Option).

If, on the one hand, the fixed revenue existing in contracts of the "by availability" modality made it possible to better forecast the future revenue of the project, on the other hand, this type of remuneration blocked the seller, if possible variable costs arose in the project. The uncertainty related to variable costs was mitigated by the new modality of New Energy contracts implemented from the 03/2018 auction.

In this way, the operational risk of generating energy in an amount lower than the contracted one also became part of the uncertainties of this type of contract, also contributing to the manager to reflect on the amount to be negotiated at auction.

\subsubsection{Real Options in New Energy contracts}

Given the uncertainties of the New Energy contracts, the most evident deal with the manager's decision as to the quantity to be offered at auction as of the last contract of 2018.

Except for the first New Energy contract, promulgated in 2011, which limited the period of anticipation of the supply period to three months, the other contracts allow the anticipation of this period without mentioning the limitation of dates, only alerting to the maintenance of prices and criteria of readjustment. 
Unlike Backup Energy contracts, New Energy contracts can negotiate the anticipated amount in the free environment, obtaining advantages from the positive variation of this price in their billing (option to Change the Operating Scale).

As for the price variation in the free environment, the manager's decision as to the amount to be auctioned is a type of decision that will depend on the forecast and variation of that price in the future, as well as the forecast of its outflow, otherwise it will be worth it negotiate an amount greater than the minimum in auctions so that the guaranteed future revenue generates a greater return to the project (switch option).

Table 7 shows the real options found in the new energy contracts based on the unmitigated uncertainties in these contracts.

Table 7. Real Options in New Energy Contracts.

\begin{tabular}{cccc}
\hline Type of Contract & Risk & Managerial Flexibility & Real Options \\
\hline New Energy & Operational & Variable Energy Anticipation Revenue Changing the operational scale \\
\hline New Energy & Operational & Amount to be traded in the ACR & Switch \\
\hline
\end{tabular}

In 2019, two new energy auctions were announced for the months of June and October, both in the "by quantity" modality, reinforcing the trend for this type of contracting.

Regarding the real options for this type of contract, it is estimated that the uncertainties will be the same as those pointed out in the evaluation of the last New Energy contract in 2018.

\section{Conclusion}

The study presented a set of risks present in wind power generation contracts in Brazil. In addition to these risks, the mitigators existing in each risk class were also presented in order to identify which Real Options could be found in the wind energy commercialization contracts in Brazil between 2009 and 2018.

Unlike most studies on the subject, which choose a source of uncertainty in order to calculate the premium that the company should pay for a given option related to uncertainty, the study identifies three main real options related to different sources of uncertainty included in the contracts Backup Energy and two real options related to the uncertainties in the New Energy contracts until mid-2018. From the change of the modality in the new energy contracts, which changed from the "by availability" mode to the "by quantity" mode, it is It is possible to affirm that the uncertainties related to the amount of energy generated no longer have the risk mitigator that was the only burden on the buyer side. With that, the real option generated by this uncertainty could also be applied in the analysis of new energy contracts.

The impossibility of negotiating the sale price of the energy generated and the variable revenue, once the price is established in an auction bid, demonstrates that the use of the variation in the sale price of the contracts as a source of uncertainty for the identification of real options it is not justified.

However, the variation of the price of the free environment can be a great measure to evaluate the real options existing in the contracts of New Energy in the modality "by quantity", whereas in contracts of Backup Energy, the best real options would be linked to the uncertainties related to the decisions to maintain or assign the amount of excess energy, in addition to those related to the plant's low operational efficiency that could compromise the amount of energy committed in the contract, generating higher than expected reimbursement costs. 
Finally, this work brought a detailed analysis of the contracts for the sale of energy from wind sources of the types of Backup energy and new energy in order to highlight the importance of the uncertainties existing in these contracts when estimating the viability of these projects. With this, it is expected that the results of this analysis will contribute to the calculation of the viability of these ventures so as not to underestimate the various risks present in information transcribed in their contracts.

\section{References}

Aquila, G., de Queiroz, A. R., Balestrassi, P. P., Rotella, P., Jr., Rocha, L. C. S., Pamplona, E. O., \& Nakamura, W. T. (2020). Wind energy investments facing uncertainties in the Brazilian electricity spot market: a real options approach. Sustainable Energy Technologies and Assessments, 42, 100876. http://dx.doi.org/10.1016/j.seta.2020.100876.

Balibrea-Iniesta, J., Sánchez-Soli, A., \& Lara-Galera, A. (2015). Application of real options theory to the assessment of public incentives for onshore wind energy development in Spain. International Journal of Energy Economics and Policy, 5(3)

Barroso, M. M., \& Iniesta, J. B. (2014). A valuation of wind power projects in Germany using real regulatory options. Energy, 77, 422-433. http://dx.doi.org/10.1016/j.energy.2014.09.027.

Bernardo, A. E., \& Chowdhry, B. (2002). Resources, real options, and corporate strategy. Journal of Financial Economics, 63(2), 211-234. http://dx.doi.org/10.1016/S0304-405X(01)00094-0.

Black, F., \& Scholes, M. (1973). The pricing of options and corporate liabilities. Journal of Political Economy, 81(3), 637-654. http://dx.doi.org/10.1086/260062.

Bodmer, E. (2014). Corporate and project finance modeling: theory and practice. Hoboken: John Wiley \& Sons. http://dx.doi.org/10.1002/9781118957394.

Boomsma, T. K., Meade, N., \& Fleten, S. E. (2012). Renewable energy investments under different support schemes: a real options approach. European Journal of Operational Research, 220(1), 225-237. http://dx.doi.org/10.1016/j.ejor.2012.01.017.

Brandão, L. E., \& Dyer, J. S. (2005). Decision analysis and real options: A discrete time approach to real option valuation. Annals of Operations Research, 135(1), 21-39. http://dx.doi.org/10.1007/s10479-005-6233-9.

Brasil. (2004). Decreto $n^{\circ} 5.163$ de 30 de Julho de 2004. Regulamenta a comercialização de energia elétrica, o processo de outorga de concessões e de autorizações de geração de energia elétrica, e dá outras providências. Brasília, DF: Diário Oficial da República Federativa do Brasil.

Brasil. (2007). Decreto $n^{\circ}$ 6.048, de 27 de Fevereiro de 2007. Altera os arts. 11, 19, 27, 34 e 36 do Decreto no 5.163, de 30 de julho de 2004, que regulamenta a comercialização de energia elétrica, o processo de outorga de concessões e de autorizações de geração de energia elétrica. Brasília, DF: Diário Oficial da República Federativa do Brasil.

Brasil. (2008). Decreto $n^{\circ}$ 6.353, de 16 de Janeiro de 2008. Regulamenta a contratação de energia de reserva de que trata o § 30 do art. 3o e o art. 3o-A da Lei no10.848, de 15 de março de 2004, altera o art. 44 do Decreto no 5.163, de 30 de junho de 2004, e o art. 2odo Decreto no 5.177, de 12 de agosto de 2004, e dá outras providências. Brasília, DF: Diário Oficial da República Federativa do Brasil.

Brasil. (2017). Decreto $n^{\circ}$ 9.143, de 22 de Agosto de 2017. Regulamenta o $\S 4^{\circ}$ do art. 27 da Lei $n$ - 10.438, de 26 de abril de 2002, e o $\S 13$ do art. $4^{\circ}$ da Lei $n^{\circ} 9.074$, de 7 de julho de 1995, altera o Decreto $n^{\circ} 5.081$, de 14 de maio de 2004, o Decreto $n^{\circ} 5.163$, de 30 de julho de 2004, o Decreto $n^{\circ} 7.246$, de 28 de julho de 2010, o Decreto $n^{\circ} 7.805$, de 14 de setembro de 2012, e o Decreto $n^{\circ}$ 9.022, de 31 de março de 2017, para dispor sobre a concessão e a comercialização de energia elétrica, e dá outras providências. Brasília, DF: Diário Oficial da República Federativa do Brasil. 
Brealey, R. A., Myers, S. C., Marcus, A. J., Wang, H., \& Zhu, L. (2007). Fundamentals of corporate finance (5th ed.). New York: McGraw-Hill.

Câmara de Comercialização de Energia Elétrica - CCEE. (2019a). Setor elétrico. Retrieved in 2019, April 13, from https://www.ccee.org.br/portal/faces/pages_publico/ondeatuamos/setor_eletrico?_adf.ctrl-state $=68 \mathrm{ttd} 253 \mathrm{~h} \_103 \&$ _afrLoop $=5168273257385$

Câmara de Comercialização de Energia Elétrica - CCEE. (2019b). Crescimento da Energia Eólica no Brasil. Retrieved in 2019, February 13, from https://www.ccee.org.br/portal/faces/pages_publico/noticias-opiniao/noticias/noticialeitura? contentid=CCEE_646081\&_afrLoop=2951736741537\&adf.ctrl-state=121xk02yzw_1

Câmara de Comercialização de Energia Elétrica - CCEE. (2019c). Histórico de preços. Retrieved in 2019, May 12, from https://www.ccee.org.br/portal/faces/pages_publico/o-quefazemos/como_ccee_atua/precos/historico?_afrLoop=301737766923167\&_adf.ctrlstate=18jtxa25v9_31\#!\%40\%40\%3F_afrLoop\%3D301737766923167\%26_adf.ctrlstate\%3D18jtxa25v9_35

Carvalho, D. B., Pinto, B. L., Guardia, E. C., \& Lima, J. W. M. (2020). Economic impact of anticipations or delays in the completion of power generation projects in the Brazilian energy market. Renewable Energy, 147, 1312-1320. http://dx.doi.org/10.1016/j.renene.2019.09.074.

Cheng, H. M., Hou, Y., \& Wu, F. F. (2010). Wind power investment in thermal system and emissions reduction. In Proceedings of the IEEE PES General Meeting (pp. 1-8). USA: IEEE. http://dx.doi.org/10.1109/PES.2010.5589659.

Collan, M., Haahtela, T., \& Kyläheiko, K. (2016). On the usability of real option valuation model types under different types of uncertainty. International Journal of Business Innovation and Research, 11(1), 18-37. http://dx.doi.org/10.1504/IJBIR.2016.077608.

Connor, R., Heffron, R. J., Khan, A. A., \& Perkins, E. (2019). Legal strategies for the mitigation of risk for energy infrastructure projects. Journal of Energy \& Natural Resources Law, 37(1), 4766. http://dx.doi.org/10.1080/02646811.2018.1455338.

Copeland, T., \& Antikarov, V. (2001). Real options. New York: Texere.

Cox, J. C., Ross, S. A., \& Rubinstein, M. (1979). Option pricing: a simplified approach. Journal of Financial Economics, 7(3), 229-263. http://dx.doi.org/10.1016/0304-405X(79)90015-1.

De Oliveira, A. M. B., Mandal, A., \& Power, G. J. (2019). A primer on the pricing of electric energy options in Brazil via mean-reverting stochastic processes. Energy Reports, 5, 594-601. http://dx.doi.org/10.1016/j.egyr.2019.03.010.

Dranka, G. G., Cunha, J., de Lima, J. D., \& Ferreira, P. (2020). Economic evaluation methodologies for renewable energy projects. AIMS Energy, 8(2), 339-364. http://dx.doi.org/10.3934/energy.2020.2.339.

Eissa, M. A., \& Tian, B. (2017). Lobatto-milstein numerical method in application of uncertainty investment of solar power projects. Energies, 10(1), 43. http://dx.doi.org/10.3390/en10010043.

Empresa de Pesquisa Energética - EPE. (2018). Participação de empreendimentos eólicos nos leilões de Energia no Brasil. Retrieved in 2019, February 10, from http://www.epe.gov.br/sitespt/publicacoes-dados-abertos/publicacoes/PublicacoesArquivos/publicacao-251/topico394/NT_EPE-DEE-NT-041_2018-r0.pdf

Eryilmaz, D., \& Homans, F. R. (2016). How does uncertainty in renewable energy policy affect decisions to invest in wind energy? The Electricity Journal, 29(3), 64-71.

http://dx.doi.org/10.1016/j.tej.2015.12.002.

Esty, B. (2014). An overview of project finance and infrastructure finance-2014 update. Massachusetts: Harvard Business Publishing.

Esty, B. C. (2004). Why study large projects? An introduction to research on project finance. European Financial Management, 10(2), 213-224. http://dx.doi.org/10.1111/j.13547798.2004.00247.x. 
Fan, J. L., Wei, S., Zhang, X., \& Yang, L. (2020). A comparison of the regional investment benefits of CCS retrofitting of coal-fired power plants and renewable power generation projects in China. International Journal of Greenhouse Gas Control, 92, 102858. http://dx.doi.org/10.1016/j.jjggc.2019.102858.

Fernandes, B., Cunha, J., \& Ferreira, P. (2011). The use of real options approach in energy sector investments. Renewable \& Sustainable Energy Reviews, 15(9), 4491-4497. http://dx.doi.org/10.1016/j.rser.2011.07.102.

Fleten, S. E., \& Maribu, K. M. (2004). Investment timing and capacity choice for small-scale wind power under uncertainty. Berkeley: LBNL.

Fleten, S.-E., Linnerud, K., Molnár, P., \& Tandberg Nygaard, M. (2016). Green electricity investment timing in practice: real options or net present value? Energy, 116, 498-506. http://dx.doi.org/10.1016/j.energy.2016.09.114.

Gatti, S. (2012). Project finance in theory and practice: designing, structuring, and financing private and public projects. Cambridge: Academic Press.

Gatti, S., Rigamonti, A., Saita, F., \& Senati, M. (2007). Measuring value-at-risk in project finance transactions. European Financial Management, 13(1), 135-158. http://dx.doi.org/10.1111/j.1468-036X.2006.00288.x.

Gazheli, A., \& van den Bergh, J. (2018). Real options analysis of investment in solar vs. wind energy: diversification strategies under uncertain prices and costs. Renewable \& Sustainable Energy Reviews, 82, 2693-2704. http://dx.doi.org/10.1016/j.rser.2017.09.096.

Graham, J., \& Harvey, C. (2002). How do CFOs make capital budgeting and capital structure decisions? Journal of Applied Corporate Finance, 15(1), 8-23. http://dx.doi.org/10.1111/j.17456622.2002.tb00337.x.

Hatata, A. Y., El-Saadawi, M. M., \& Saad, S. (2019). A feasibility study of small hydro power for selected locations in Egypt. Energy Strategy Reviews, 24, 300-313. http://dx.doi.org/10.1016/j.esr.2019.04.013.

Jorion, P., \& Zhang, G. (2009). Credit contagion from counterparty risk. The Journal of Finance, 64(5), 2053-2087. http://dx.doi.org/10.1111/j.1540-6261.2009.01494.x.

Kitzing, L., Juul, N., Drud, M., \& Boomsma, T. K. (2017). A real options approach to analyse wind energy investments under different support schemes. Applied Energy, 188, 83-96. http://dx.doi.org/10.1016/j.apenergy.2016.11.104.

Kleimeier, S., \& Versteeg, R. (2010). Project finance as a driver of economic growth in low-income countries. Review of Financial Economics, 19(2), 49-59. http://dx.doi.org/10.1016/j.rfe.2010.01.002.

Kozlova, M. (2017). Real option valuation in renewable energy literature: research focus, trends and design. Renewable \& Sustainable Energy Reviews, 80, 180-196. http://dx.doi.org/10.1016/j.rser.2017.05.166.

Lambrecht, B. M. (2017). Real options in finance. Journal of Banking \& Finance, 81, 166-171. http://dx.doi.org/10.1016/j.jbankfin.2017.03.006.

Li, Y., Wu, M., \& Li, Z. (2018). A real options analysis for renewable energy investment decisions under China carbon trading market. Energies, 11(7), 1817. http://dx.doi.org/10.3390/en11071817.

Liu, X., \& Ronn, E. I. (2020). Using the binomial model for the valuation of real options in computing optimal subsidies for Chinese renewable energy investments. Energy Economics, 87, 104692. http://dx.doi.org/10.1016/j.eneco.2020.104692.

Locatelli, G., Mancini, M., \& Lotti, G. (2020). A simple-to-implement real options method for the energy sector. Energy, 197, 117226. http://dx.doi.org/10.1016/j.energy.2020.117226.

Madlener, R., Glensk, B., \& Gläsel, L. (2019). Optimal timing of onshore wind repowering in germany under policy regime changes: a real options analysis. Energies, 12(24), 4703. http://dx.doi.org/10.3390/en12244703. 
Maeda, M., \& Watts, D. (2019). The unnoticed impact of long-term cost information on wind farms' economic value in the USA. A real option analysis. Applied Energy, 241, 540-547. http://dx.doi.org/10.1016/j.apenergy.2018.11.065.

Martinez-Cesena, E. A., \& Mutale, J. (2011). Wind power projects planning considering real options for the wind resource assessment. IEEE Transactions on Sustainable Energy, 3(1), 158-166. http://dx.doi.org/10.1109/TSTE.2011.2164102.

Méndez, M., Goyanes, A., \& Fernandez, P. L. (2009). Real options valuation of a wind farm. SSRN. http://dx.doi.org/10.2139/ssrn.2708351.

Muñoz, J. I., Contreras, J., Caamano, J., \& Correia, P. F. (2009, june). Risk assessment of wind power generation project investments based on real options. In Proceedings of the 2009 IEEE Bucharest PowerTech (pp. 1-8). USA: IEEE. http://dx.doi.org/10.1109/PTC.2009.5281848.

Muñoz-Hernández, J. I., Contreras, J., Caamaño, J., \& Correia, P. F. (2009). Risk assessment of wind power generation project investments based on real options. In Proceedings from the 13th International Congress on Project Engineering. Badajoz.

Myers, S. C. (1977). Determinants of corporate borrowing. Journal of Financial Economics, 5(2), 147-175. http://dx.doi.org/10.1016/0304-405X(77)90015-0.

Myers, S. C., \& Majd, S. (2001). Abandonment value and project life. In E. S. Schwartz \& L. Trigeorgis (Eds.), Real options and investment under uncertainty: classical readings and recent contributions (pp. 295-312). Cambridge: MIT Press.

Nevitt, P. K., \& Fabozzi, F. J. (2000). Project financing (7th ed.). London: Euromoney Books.

Onar, S. Ç., \& Kilavuz, T. N. (2015). Risk analysis of wind energy investments in Turkey. Human and Ecological Risk Assessment, 21(5), 1230-1245. http://dx.doi.org/10.1080/10807039.2014.955387.

Pelajo, J. C., Brandão, L. E., Gomes, L. L., \& Klotzle, M. C. (2019). Wind farm generation forecast and optimal maintenance schedule model. Wind Energy (Chichester, England), 22(12), 18721890. http://dx.doi.org/10.1002/we.2405.

Penizzotto, F., Pringles, R., \& Olsina, F. (2019). Real options valuation of photovoltaic power investments in existing buildings. Renewable \& Sustainable Energy Reviews, 114, 109308. http://dx.doi.org/10.1016/j.rser.2019.109308.

Pindyck, R. S. (1986). Irreversible investment, capacity choice, and the value of the firm (Working Paper, NBER Working Paper Series, no. 1980). Cambridge: National Bureau of Economic Research. http://dx.doi.org/10.3386/w1980.

Reuter, W. H., Szolgayová, J., Fuss, S., \& Obersteiner, M. (2012). Renewable energy investment: policy and market impacts. Applied Energy, 97, 249-254. http://dx.doi.org/10.1016/j.apenergy.2012.01.021.

Ritzenhofen, I., \& Spinler, S. (2016). Optimal design of feed-in-tariffs to stimulate renewable energy investments under regulatory uncertainty: a real options analysis. Energy Economics, 53, 7689. http://dx.doi.org/10.1016/j.eneco.2014.12.008.

Santos, L., Soares, I., Mendes, C., \& Ferreira, P. (2014). Real options versus traditional methods to assess renewable energy projects. Renewable Energy, 68, 588-594. http://dx.doi.org/10.1016/j.renene.2014.01.038.

Trigeorgis, L. (1999). Real options: a primer. In J. J. Alleman \& E. M. Noam (Eds.), The new investment theory of real options and its implication for telecommunications economics. New York: Springer.

Trigeorgis, L. (2007). Opções reais e interações com a flexibilidade financeira. Revista de Administração de Empresas, 47(3), 95-120. http://dx.doi.org/10.1590/S003475902007000300014.

Venetsanos, K., Angelopoulou, P., \& Tsoutsos, T. (2002). Renewable energy sources project appraisal under uncertainty: the case of wind energy exploitation within a changing energy 
market environment. Energy Policy, 30(4), 293-307. http://dx.doi.org/10.1016/S03014215(01)00096-9.

Wesseh, P. K., Jr., \& Lin, B. (2016). A real options valuation of Chinese wind energy technologies for power generation: do benefits from the feed-in tariffs outweigh costs? Journal of Cleaner Production, 112, 1591-1599. http://dx.doi.org/10.1016/j.jclepro.2015.04.083.

Yescombe, E. R. (2002). Principles of project finance. San Diego, CA: Elsevier.

Yu, W., Sheblé, G. B., Lopes, J. A. P., \& Matos, M. A. (2006). Valuation of switchable tariff for wind energy. Electric Power Systems Research, 76(5), 382-388. http://dx.doi.org/10.1016/j.epsr.2005.09.004.

Zhang, M. M., Zhou, P., \& Zhou, D. Q. (2016). A real options model for renewable energy investment with application to solar photovoltaic power generation in China. Energy Economics, 59, 213-226. http://dx.doi.org/10.1016/j.eneco.2016.07.028.

Zhang, R., Shimada, K., Ni, M., Shen, G. Q., \& Wong, J. K. (2020). Low or No subsidy? Proposing a regional power grid based wind power feed-in tariff benchmark price mechanism in China. Energy Policy, 146, 111758. http://dx.doi.org/10.1016/j.enpol.2020.111758. 